DOI:

УДК 681.5.015.23:681.5.015.24

А.М. Мацуй, к.т.н., доцент, matsuyan@ukr.net

В.О. Кондратець, д.т.н., професор, matsuyan@ukr.net

Центральноукраїнський національний технічний університет, м. Кропивницький

\title{
МОДЕЛЮВАННЯ ОТРИМАННЯ І ОЦІНЮВАННЯ РЕЗУЛЬТУЮЧИХ ХАРАКТЕРИСТИК КУЛЬОВОГО НАВАНТАЖЕННЯ РУДОРОЗМЕЛЬНОГО МЛИНА ПЕРШОЇ СТАДІЇ
}

В роботі проаналізовано вплив факторів і розглянуто закономірності спраџювання молольного середовища. Промодельовано характеристики крупності кульового навантаження при однорозмірних кулях і проаналізовано використання суміші різнорозмірних куль. Запропоновано метод побудови результуючої характеристики різнорозмірного кульового навантаження млина. Розроблено критерій оцінювання наближення результуючої характеристики різнорозмірного кульового навантаження до ідеалізованої та доведена можливість його реалізаціï.

Ключові слова: кульовий млин; результуюча характеристика; різнорозмірне кульове навантаження.

The paper analyzes the influence of factors and considers the patterns of operation of the grinding medium. The characteristics of the size of the ball load with one-dimensional balls are modeled and the use of a mixture of multi-sized balls is analyzed. A method for constructing the resulting characteristics of a multi-size ball load of the mill is proposed. A criterion for estimating the approximation of the resulting characteristic of a multi-size ball load to the idealized one is developed and the possibility of its realization is proved.

Keywords: ball mill; resulting characteristic; multi-size ball load.

\section{Постановка проблеми}

Продукція вітчизняної чорної металургії програє на міжнародному ринку в конкуренції. Поправити такий стан можливо рядом заходів, серед яких важливим $є$ автоматична стабілізація оптимального кульового навантаження млинів перших стадій подрібнення руди, яка нині не здійснюється.

Дана проблема відображається в державних документах і $є$ складовою наукової тематики ряду організацій, в тому числі і Центральноукраїнського національного технічного університету, який виконує теми «Комп'ютеризована система ідентифікації завантаження кульового млина при управлінні подрібненням руди» (0109U007939) та «Оптимізація продуктивності кульових млинів по руді і готовому продукту при мінімальних енергетичних і матеріальних перевитратах» (0115U003942). Вpaховуючи, що дана стаття спрямована на розв'язання цієї задачі, iї тема $є$ актуальною.

\section{Аналіз останніх досліджень та публікацій}

Розробці даного наукового напряму присвячено чимало робіт, однак вони спрямовувалися в основному на завантаження млинів кулями. Дослідження продовжуються і в теперішній час. Так, запропоновано метод нечіткого контролю для систем з кульовими млинами на основі чутливого датчика рівня заповнення барабана [1], завантаження млина шляхом аналізу вібраційних сигналів $[2,3,4]$, визначення поведінки навантаження промислового барабанного млина за результатами обробки шумових і вібраційних сигналів [5]. Найвищим досягненням є запропонована методологія оцінки рівня заповнення млина на основі спектрального аналізу крутного моменту [6]. В цій статті стверджується, що сигнал крутного моменту в кульових млинах містить достатню інформацію, щоб однозначно характеризувати рівень навантаження млина. Однак відомо, що потужність, яка споживається кульовим млином, слабко залежить від власне процесу руйнування і скорочення розміру часток твердого [7], мають місце і інші збурні фактори. В той же час практикою подрібнення руд кольорових металів в Росії, США, Канаді доведено, що млини, які завантажені кулями чотирьох-п'яти типорозмірів, мають на $10 \ldots 15 \%$ більш високу продуктивність порівняно $з$ технологічними агрегатами, завантаженими однорозмірни- 
ми кулями [8]. Це ж саме підкреслює в роботі [9] А.А. Яценко, а Е.А. Хопунов в [10] відмічає низьку ефективність руйнування руди в кульових млинах, однією з причин якої є відсутність раціонного довантаження куль. Гальмом в цьому, зокрема, $є$ відсутність підходів формування складу раціонного кульового навантаження млинів. Нині розроблено лише графоаналітичні методи визначення характеристики крупності кульового навантаження в млині при раціонному довантаженні куль та встановлення необхідного складу раціонного довантаження для отримання заданої характеристики крупності кульового навантаження [11]. Однак для цього необхідно знати діаметри куль i їх масу відповідно розмірам, що саме і складає основну задачу розв'язання раціонного складу і довантаження молольного середовища. Отже, задача визначення раціонного складу молольного середовища в кульових млинах на сьогодні не вирішена.

\section{Формулювання мети дослідження}

Метою даної публікації є моделювання отримання і оцінювання результуючих характеристик різнорозмірного кульового навантаження рудорозмельних млинів першої стадії з тим, щоб забезпечити їх найбільшу продуктивність.

Для досягнення поставленої мети необхідно вирішити наступні задачі:

- проаналізувати вплив факторів на спрацювання куль;

- розглянути закономірності спрацювання молольного середовища;

- промоделювати характеристики крупності кульового навантаження при однорозмірних кулях;

- проаналізувати використання суміші різнорозмірних куль;

- розробити метод побудови результуючої характеристики крупності різнорозмірного кульового навантаження млина;

- розробити критерій оцінювання наближення результуючої характеристики до ідеалізованої;

- довести можливість реалізації критерію оцінювання наближення результуючої та ідеалізованої характеристик.

\section{Аналіз впливу факторів на спрацювання куль}

При подрібненні руди в барабанних млинах кулі спрацьовуються. Спрацювання молольних тіл залежить віл багатьох факторів — матеріалу і способу їх виготовлення, розмірів і маси, діаметра барабана та швидкості його обертання, властивостей і крупності подрібнюваної руди, розрідження пульпи, кінцевої крупності подрібнення, типу футеровки, режиму роботи та ін. Як показує аналіз, в конкретних випадках багато 3 цих факторів стають незмінними. Так, діаметр барабана і швидкість його обертання, тип футеровки і режим роботи технологічного агрегату вибираються зарані і не змінюються. Технологічним процесом визначається конкретний різнотип руди, її крупність, кінцева крупність подрібнення і розрідження пульпи, які також стають незмінними. Значно зручніше і доцільніше працювати на кулях, виготовлених з конкретного матеріалу за певною технологією, що також легко стабілізується. Отже, практично всі фактори впливу, крім розміру і маси куль, в конкретних умовах подрібнення вихідної руди на збагачувальних фабриках є незмінними або їх можливо зробити такими.

В процесі спрацювання молольного середовища при подрібненні руди змінюється характеристика кульового навантаження млина. Це складний процес, однак встановлені закономірності для одного базового випадку, коли технологічний агрегат завантажено однорозмірними кулями, знос яких поповнюється такими ж тілами при спрацюванні попередніх. При цьому, після спрацювання первинного молольного навантаження, в кульовому млині встановлюється склад різнорозмірних куль 3 незмінною характеристикою крупності кульового навантаження. Це забезпечує незмінність умов подрібнення руди, але через переважання крупних куль продуктивність виявляється заниженою. Тому необхідно знайти умови підвищення продуктивності технологічного агрегату до найвищого рівня шляхом удосконалення кульового навантаження 3 залученням теорії спрацювання молольного середовища.

\section{Закономірності спрацювання молольного середовища}

Закономірності спрацювання молольного середовища, виражені через гіпотези, узагальнив К.О. Разумов [11]. Запропоновано швидкість спрацювання куль визначати рівнянням 


$$
\frac{d G}{d t}=-k D_{M}^{m}
$$

де $G$ - маса кулі в момент початку спрацювання, кг; $k$ - коефіцієнт пропорціональності; $t$ тривалість спрацювання; $D_{M}$ - початковий діаметр кулі, см; $m$ - величина, що змінюється в залежності від режиму роботи млина в межах від 2 до 3.

У формулі (1) значення $m=2$ відповідає каскадному режиму роботи, $m=3$ - водоспадному режиму роботи. В проміжку між 2 і 3 параметр $m$ відповідає змішаному режиму роботи.

Відповідно узагальненій гіпотезі (1) щодо швидкості зносу куль у кульовому млині можливо для характеристики кульового навантаження за плюс $D$ записати рівняння виходу $Z$ куль певного розміру [11]

$$
Z=100\left[1-\left(\frac{D}{D_{M}}\right)^{n}\right]=100 \frac{D_{M}^{n}-D^{n}}{D_{M}^{n}},
$$

де $D$ - діаметр кулі, що розглядається, $D<D_{M} ; n=6-m[11]$.

Залежність (2) дозволяє будувати характеристики крупності молольного середовища після спрацювання початкового навантаження млина. При цьому отримуємо молольне навантаження, в якому переважають крупні кулі і не забезпечується найкраща продуктивність в наслідок невистачання дрібних і середніх молольних тіл, які на одиницю об'єму забезпечують більшу поверхню.

Моделювання характеристик крупності кульового навантажсення при однорозмірних кулях

При побудові характеристик крупності молольного середовища за рівнянням (2) враховують початкове значення діаметра куль $D_{M}$ і кінцеве значення $D_{K}=0$, до якого спрацьовується подрібнююче тіло, тобто, воно повинно повністю стертися. Кулі ж в млині звичайно використовують при зменшенні їх діаметра до $15 \ldots 20$ мм [11]. За залежністю (2) з врахуванням $D_{K}=0$ виконаємо розрахунки і побудуємо характеристики крупності кульового навантаження при різних початкових значеннях діаметра $D_{M}$, які приведені на рис. 1 . Крім того, тут приведені ідеалізовані характеристики крупності кульового навантаження 1', 2', 3'. 3 залежностей 1, 2, 3 видно, що точні характеристики крупності кульового навантаження є випуклими. Випуклість залежить

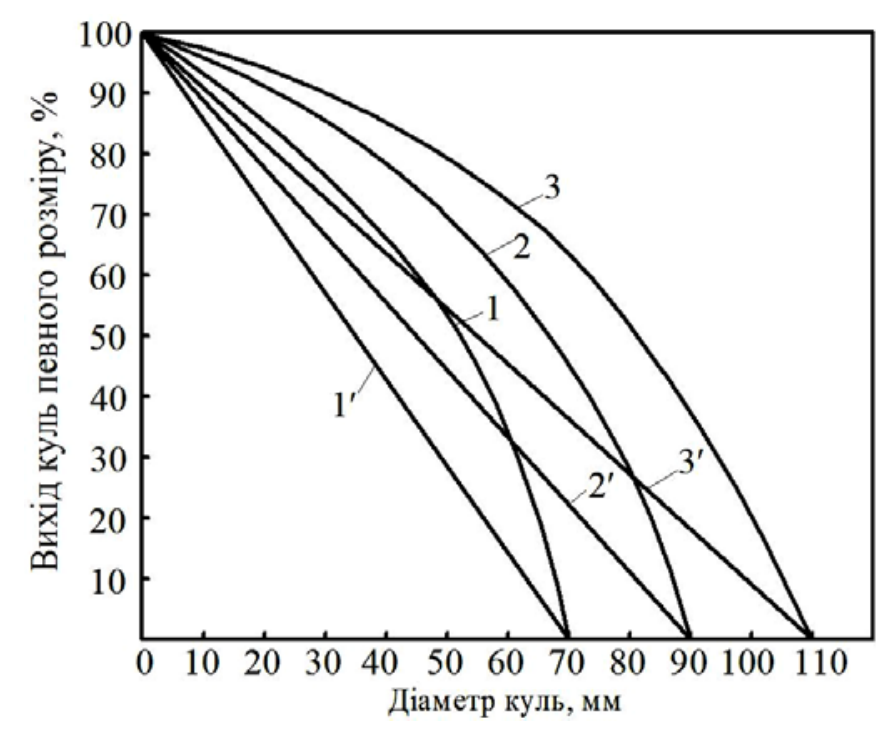

1, 2, 3 - точні; 1', 2', 3' — ідеалізовані

Puc. 1. Характеристики крупності кульового навантаження млина, що працює на однорозмірних кулях, при різних початкових розмірах від початкового значення діаметра кулі $D_{M}$. Чим більше значення початкового діаметра, тим більша випуклість характеристики. Отже, чим більший початковий розмір куль, тим більша середня їх крупність у навантаженні млина. Таке кульове навантаження тим більше не буде забезпечувати високої продуктивності технологічного агрегату. Це не можливо сказати про ідеалізовані характеристики 1', 2', 3'.

Забезпечення найвищої продуктивності технологічного агрегату, як слідує 3 рис. 1, буде визначатись початковим розміром найбільшої кулі та степеню наближення реальної характеристики кульового навантаження до ідеалізованої. Характеристики крупності кульового навантаження млинів необхідно уточнювати експериментальним шляхом [12].

Для подрібнення руди крупніс-

тю 25...0 мм використовують кулі діаметром 100..125 мм. Кулі діаметром 80...90 мм призначені для подрібнення руди дрібніше $12 \ldots 0$ мм. Отже, за відомою крупністю руди на вході кульо- 
вого млина можливо визначити найбільший початковий діаметр куль у навантаженні. Якщо руда міцна і має крупність $12 \ldots 0$ мм, то найбільший діаметр куль слід прийняти $D_{M}=90$ мм. У випадку міцної вихідної руди крупністю $25 \ldots 0$ мм слід прийняти $D_{M}=120 \ldots 125$ мм. Як видно, вибір значення $D_{M}$ спрощується і не викликає особливих труднощів. Цьому також сприяє можливість встановлення середньозваженої крупності твердого в завантаженні кульового млина [13].

\section{Аналіз використання суміші різнорозмірних куль}

Як відомо, використання суміші куль різного діаметра може суттєво підвищити ефективність роботи вузла подрібнення. Тому початкове кульове навантаження складемо 3 кількох розмірів куль, базовим 3 яких буде $D_{M}$, наприклад, $D_{M}=90$ мм при крупності міцної руди $12 \ldots 0$ мм. Оскільки обмеження кількості куль більших 80 мм у кульовому завантаженні млина може суттєво підвищити ефективність його роботи [9], кількість таких куль слід обирати порівняно невеликою. Для спрощення приймемо чотири типорозміри куль.

В таких розрахунках звичайно «здійснюють» подрібнення до повного спрацювання куль усіх прийнятих розмірів. Різнорозмірне кульове навантаження млина повинно мати певну характеристику крупності, яка б забезпечувала високу продуктивність технологічного агрегату. Це можливо при достатньо близькому розташуванні характеристики різнорозмірного кульового навантаження до ідеалізованої. Засобами впливу тут можуть бути: кількість видів куль; інтервал між прийнятими розмірами куль; мінімальний розмір кулі; вміст куль кожного розміру. Використовуючи засоби впливу на характеристику кульового навантаження, необхідно обрати параметр оцінювання. Ним може бути відхилення дійсної характеристики різнорозмірного кульового навантаження від ідеалізованої. Однак для цього необхідно мати характеристики кульового навантаження млина, яке складене 3 кількох типорозмірів молольних тіл.

Метод побудови результуючої характеристики крупності кульового навантаження млина

В роботі [11] запропоновано графоаналітичний підхід побудови результуючої характеристики різнорозмірного кульового навантаження млина, яке складається з кількох типорозмі-

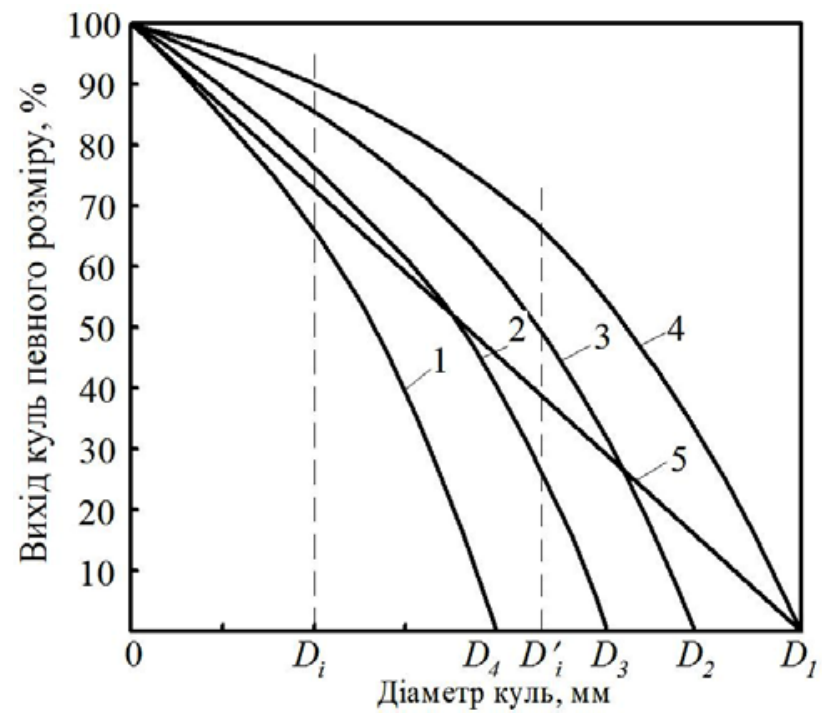

1 - для куль діаметром $D_{4} ; 2-D_{3} ; 3-D_{2} ; 4-D_{1}$

Puc. 2. Результуючі характеристики крупності кульового навантаження при регулярному живленні однорозмірними кулями $D_{1}, D_{2}, D_{3}, D_{4}$ і повному спрацюванні первинних завантажених моло- рів молольних тіл, однак метод достатньо складний i його практично не можливо застосувати на практиці. В даній роботі запропоновано інший підхід, який відрізняється гнучкістю i може бути застосований при машинній обробці даних. Аналіз показав, що результуючу характеристику крупності різнорозмірного кульового навантаження млина можливо отримати за результуючими характеристиками крупності кульового навантаження, що створюється при регулярному його живленні лише однорозмірними кулями максимального діаметра і повному спрацюванні первинних тіл. Для обраних діаметрів куль вони показані на рис. 2. Вони отримані за залежністю (2). Змішане кульове навантаження початково складається 3 куль діаметром $D_{1}$, і вмістом $w_{1}$ відсотків, діаметром $D_{2}$ і вмістом $w_{2}$, діаметром $D_{3} \mathrm{i}$ вмістом $w_{3}$, діаметром $D_{4}$ і вмістом $w_{4}$, причому $\quad w_{1}+w_{2}+w_{3}+w_{4}=100 \%$. Кількість розмірів куль, інтервал між ними, мінімальний розмір кулі та відсотковий вміст молольних тіл певного розміру задаються в процесі моделювання. 
При побудові характеристики кульового навантаження млина розглядають почергово всі діаметри куль, наприклад кулі діаметром $D_{i}$ (рис. 2). Відповідно характеристикам 1, 2, 3, 4 (рис. 2) визначають ординати. Кожну з них множать на коефіцієнт, що відповідає вмісту куль даного розміру в кульовому навантаженні. Коефіцієнти відповідно дорівнюють $k_{1}=\frac{w_{1}}{100}$, $k_{2}=\frac{w_{2}}{100}, k_{3}=\frac{w_{3}}{100}, k_{4}=\frac{w_{4}}{100}$. Сума скоректованих ординат характеристик дорівнює ординаті результуючої характеристики змішаного кульового навантаження для діаметра куль $D_{i}$. Визначивши ординати для всіх діаметрів і з'єднавши точки між собою, отримуємо результуючу характеристику крупності різнорозмірного кульового навантаження. Якщо при визначенні результуючої ординати, наприклад для $D_{i}$, одна 3 характеристик, наприклад 1 , не входить, то цей член відповідно опускається і не враховується в загальний результат. Даний підхід отримання характеристики крупності різнорозмірного кульового навантаження млина доцільно реалізовувати на персональному комп'ютері. Отримана результуюча характеристика крупності повинна достатньо близько розташовуватися біля ідеалізованої характеристики 5 (рис. 2) різнорозмірного кульового навантаження млина. Найкращим рішенням було б повне співпадіння даних залежностей, однак це не можливо, оскільки характеристики 1, 2, 3, i 4 є нелінійними, а 5 являє собою пряму. Тому необхідно ввести критерій, який би оцінював степінь наближення цих характеристик одна до одної.

\section{Критерій оцінювання наближення результуючої характеристики до ідеалізованої}

Аналіз показує, що степінь наближення ідеалізованої і результуючої характеристик можливо оцінити певним критерієм. Для отримання таких оцінок необхідно визначати степінь відхилення результуючої характеристики кульового навантаження від ідеалізованої для кожного значення діаметра кулі. Найкраще це робити аналітичним шляхом. Запропонований підхід отримання результуючої характеристики різнорозмірного кульового навантаження млина дозволяє це здійснити, однак ще необхідне рівняння ідеалізованої характеристики 5 (рис. 2). Це пряма, яка приходить через дві точки $[100 ; 0]$ i $\left[0 ; D_{1}\right]$ в декартовій системі координат на рис. 2. Для неї справедлива залежність

$$
\frac{W-100}{0-100}=\frac{D_{i}}{D_{1}}
$$

звідки

$$
W=100\left(1-\frac{D_{i}}{D_{1}}\right), \%
$$

де $w$ - ваговий процентний вміст куль діаметром $D_{i} ; D_{i}$ - діаметр куль, що розглядається; $D_{1}$ - найбільше значення діаметра куль.

Ординату реальної результуючої характеристики різнорозмірного кульового навантаження млина визначимо відповідно залежності

$$
Z_{p i}=100\left[\left(k_{1}+k_{2}+k_{3}+k_{4}\right)-\left(\frac{D_{i}^{2}}{D_{1}^{2}} k_{1}+\frac{D_{i}^{2}}{D_{2}^{2}} k_{2}+\frac{D_{i}^{2}}{D_{3}^{2}} k_{3}+\frac{D_{i}^{2}}{D_{4}^{2}} k_{4}\right)\right] .
$$

Рівняння (4) дозволяє знаходити ординати для куль, діаметр яких менший мінімального діаметра куль, які входять до складу первинного завантаження і дозавантаження.

Якщо ж визначаються ординати для куль, що мають розміри, більші деяких куль у первинному завантаженні і дозвантаженні кульового млина, то в рівнянні (4) деякі члени прибираються. Наприклад, $D_{i}>D_{4}$. Тоді у виразі (4) необхідно не враховувати члени $k_{4}$ (вираз у перших круглих дужках) i $\frac{D_{i}^{2}}{D_{4}^{2}} k_{4}$ (вираз у других круглих дужках). Для даного випадку ордината для $D_{i}>D_{4}$ визначиться залежністю 


$$
Z_{p i}=100\left[\left(k_{1}+k_{2}+k_{3}\right)-\left(\frac{D_{i}^{2}}{D_{1}^{2}} k_{1}+\frac{D_{i}^{2}}{D_{2}^{2}} k_{2}+\frac{D_{i}^{2}}{D_{3}^{2}} k_{3}\right)\right] .
$$

Аналогічно з рівнянням (4) можуть виключатись відповідно члени для $D_{i}>D_{3}$ і воно прийме вигляд

$$
Z_{p i}=100\left[\left(k_{1}+k_{2}\right)-\left(\frac{D_{i}^{2}}{D_{1}^{2}} k_{1}+\frac{D_{i}^{2}}{D_{2}^{2}} k_{2}\right)\right],
$$

при $D_{i}>D_{2}$ рівняння буде наступним:

$$
Z_{p i}=100\left(k_{1}-\frac{D_{i}^{2}}{D_{1}^{2}} k_{1}\right)=100 k_{1}\left(1-\frac{D_{i}^{2}}{D_{1}^{2}}\right) .
$$

Відхилення результуючої характеристики різнорозмірного кульового навантаження від ідеалізованої при діаметрі куль $D_{i}$ дорівнює різниці ординат, тобто

$$
\Delta Z_{i}=\left[\left(k_{1}+k_{2}+k_{3}+k_{4}\right)-\left(\frac{D_{i}^{2}}{D_{1}^{2}} k_{1}+\frac{D_{i}^{2}}{D_{2}^{2}} k_{2}+\frac{D_{i}^{2}}{D_{3}^{2}} k_{3}+\frac{D_{i}^{2}}{D_{4}^{2}} k_{4}\right)\right]-\left(1-\frac{D_{i}}{D_{1}}\right) .
$$

В залежності від значень $D_{i}$ у лівій частині (8) в якості зменшуваного може знаходитись відповідно права частина виразів (5), (6) або (7). При обході всього діапазону зміни діаметрів куль кульового навантаження млина від 0 до $D_{i}$, будуть отримані додатні та від'ємні відхилення $\Delta Z_{i}$ результуючої характеристики 1 від ідеалізованої 2 (рис. 3). Однак ці відхилення викривлено характеризують процес наближення характеристик, оскільки вони розташовані не під прямим кутом до ідеалізованої характеристики 2. Відхилення результуючої характеристики 1 від ідеалізованої 2 при даному діаметрі кулі $D_{i}$ можливо визначати з трикутника $\triangle A B C$. Воно буде дорівнювати

$$
\Delta Z_{i}^{\prime}=A B=B C \cdot \sin \alpha=\Delta Z_{i} \sin \alpha .
$$

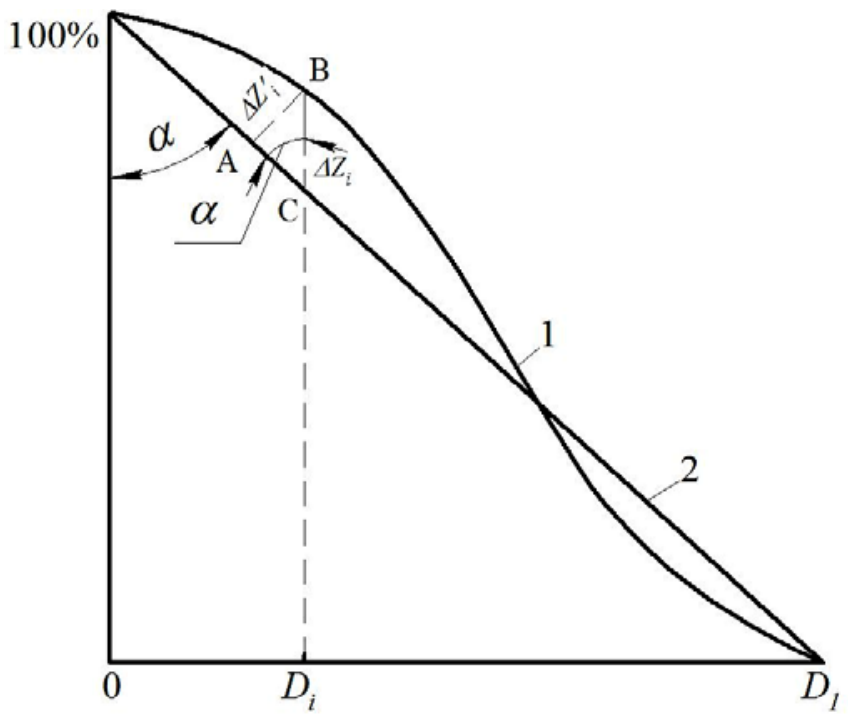

Рис. 3. Визначення відхилення результуючої характеристики 1 від ідеалізованої 2 різнорозмірного кульового навантаження млина

Однак для цього необхідно визначити кут $\alpha$ (рис. 3). При розв'язанні прямокутних трикутників враховують довжину їх сторін. У даному випадку сторони задані різними величинами - мм i \%, тому їх необхідно привести до однієї міри вимірювання. Ведучою величиною тут $\epsilon$ найбільший діаметр кулі $D_{1}$, тому сторони трикутника необхідно виражати в мм, прийнявши масштаб $1 \%=1$ мм. Тоді $\operatorname{tg} \alpha=D_{1} / 100 \%=D_{1}$, мм $/ 100$ мм. Діаметр найбільшої кулі у кульовому завантаженні виступає базовою величиною. Якщо $D_{1}=120 \mathrm{мм}, \operatorname{tg} \alpha=1,2$, $\alpha=50^{\circ} 10^{\prime}$. При $D_{1}=100$ мм, $\operatorname{tg} \alpha=1$, $\alpha=45^{\circ}, \quad$ при $D_{1}=90$ мм, $\operatorname{tg} \alpha=0,9$, $\alpha=42^{\circ}$, при $D_{1}=80$ мм, $\operatorname{tg} \alpha=0,8$, $\alpha=38^{\circ} 40^{\prime}$. Кут $\alpha$ буде незмінним при вибраному діаметрі $D_{1}$ найбільшої кулі різнорозмірного кульового навантаження млина. Здійснивши розрахунки для прийнятих і менших стандартизованих діаметрів куль у кульовому навантаженні, визначаємо ординати результуючої характеристики 1 змішаного кульового навантаження млина відносно його ідеалізованої характеристики 2. Апроксимуючи розрахункові дані, отримуємо аналітичну залежність $Z(D)$, яка характеризує процес відхилення результуючої характеристики 1 від 
ідеалізованої 2. Мірою (критерієм) найкращого наближення характеристик 1 і 2 буде мінімум сумарної площі, обмеженої даними залежностями. Для цього підходить квадратична інтегральна оцінка запропонована для систем автоматичного керування А.А. Красовським

$$
J_{2}=\int_{0}^{D_{1}}\left[\Delta Z_{i}^{\prime}(D)\right]^{2} d D
$$

Функцію $\Delta Z_{i}^{\prime}(D)$ знаходимо апроксимуванням значень $\Delta Z_{i}^{\prime}$, визначених для прийнятих діаметрів куль та їх стандартизованих розмірів, менших найменшого прийнятого значення.

\section{Доведення можсливості реалізації критерію оцінювання наближення результуючої та ідеалізованої характеристик}

Доведення здійснимо на чотирьох прикладах, дані початкового кульового навантаження яких приведені в табл. 1.

Таблиия 1. Ваговий вміст куль певного розміру у різнорозмірному початковому навантаженні млина, \%

\begin{tabular}{|c|c|c|c|c|c|c|c|c|c|c|c|c|c|}
\hline \multirow{2}{*}{$\begin{array}{c}\text { Варіант пер- } \\
\text { винного на- } \\
\text { вантаження } \\
\text { млина }\end{array}$} & \multicolumn{13}{|c|}{ Діаметр куль, мм } \\
\hline & 0 & 25 & 40 & 50 & 55 & 65 & 70 & 75 & 80 & 90 & 100 & 110 & 120 \\
\hline Перший & 0 & - & 25 & - & 25 & - & 25 & - & - & 25 & - & - & - \\
\hline Другий & 0 & - & 26 & - & 35 & - & 27 & - & - & 12 & - & - & - \\
\hline Виробничий & 0 & - & 25 & - & - & - & - & - & 20 & - & 35 & 20 & - \\
\hline Оптимальний & 0 & - & - & 18 & - & 23 & - & 27 & - & 32 & - & - & - \\
\hline
\end{tabular}

Застосовуючи запропонований метод побудови результуючої характеристики кульового навантаження млина за залежністю (9) знаходились іiі ординати $\Delta Z_{i}^{\prime}$. Дані розрахунків приведені в табл. 2. 3 даних табл. 2 слідує, що всі результуючі характеристики різнорозмірного кульового навантаження млина у функції діаметра кулі змінюються циклічно. Результуючі характеристики за усіма варіантами апроксимувалися математичними залежностями у вигляді поліномів, суми синусів і ряду Фур'є. Апроксимація виконувалася в Curve Fitting Toolbox - наборі графічних інтерфейсів (GULs) і M - функцій для користувачів, які створені в обчислювальномy середовищі MATLAB. При цьому отримані аналітичні залежності відхилення результуючої характеристики від ідеалізованої $f(x)$ у відсотках у функції діаметра кулі $x$, поданого в мм.

Таблиия 2. Відхилення результуючої характеристики від ідеалізованої у різнорозмірних навантаженнях кульового млина, \%

\begin{tabular}{|c|c|c|c|c|c|c|c|c|c|c|c|c|c|}
\hline $\begin{array}{c}\text { Варіант } \\
\text { первин- } \\
\text { ного на- } \\
\text { ванта- } \\
\text { ження } \\
\text { млина }\end{array}$ & 0 & 25 & 40 & 50 & 55 & 65 & 70 & 75 & 80 & 90 & 100 & 110 & 120 \\
\hline Перший & 0 & $+7,73$ & $-6,88$ & - & $-13,66$ & - & - & - & - & 0 & - & - & - \\
\hline Другий & 0 & $+6,0$ & $-11,26$ & - & $-20,04$ & - & - & - & - & 0 & - & - & - \\
\hline $\begin{array}{c}\text { Вироб- } \\
\text { ничий }\end{array}$ & 0 & $+6,05$ & $-4,49$ & - & - & - & - & - & - & - & - & - & 0 \\
\hline $\begin{array}{c}\text { Оптима- } \\
\text { льний }\end{array}$ & 0 & $+14,4$ & - & $+2,12$ & - & - & - & - & - & - & - & - & - \\
\hline
\end{tabular}


Результати апроксимування результуючих характеристик різнорозмірного кульового навантаження млина за першим варіантом різними підходами приведені на рис. 4. Вздовж осі ординат $Y$ відкладені відхилення $\Delta Z_{i}^{\prime} \equiv f(x)$ у процентах. 3 рис. 4 видно, що поліноміальним підходом (рис. 4, a) і рядом Фур'є (рис. 4, в) характеристики описуються точно. Сумою синусів такої точності не досягається. Тому ці дослідження необхідно розглянути більш докладніше.
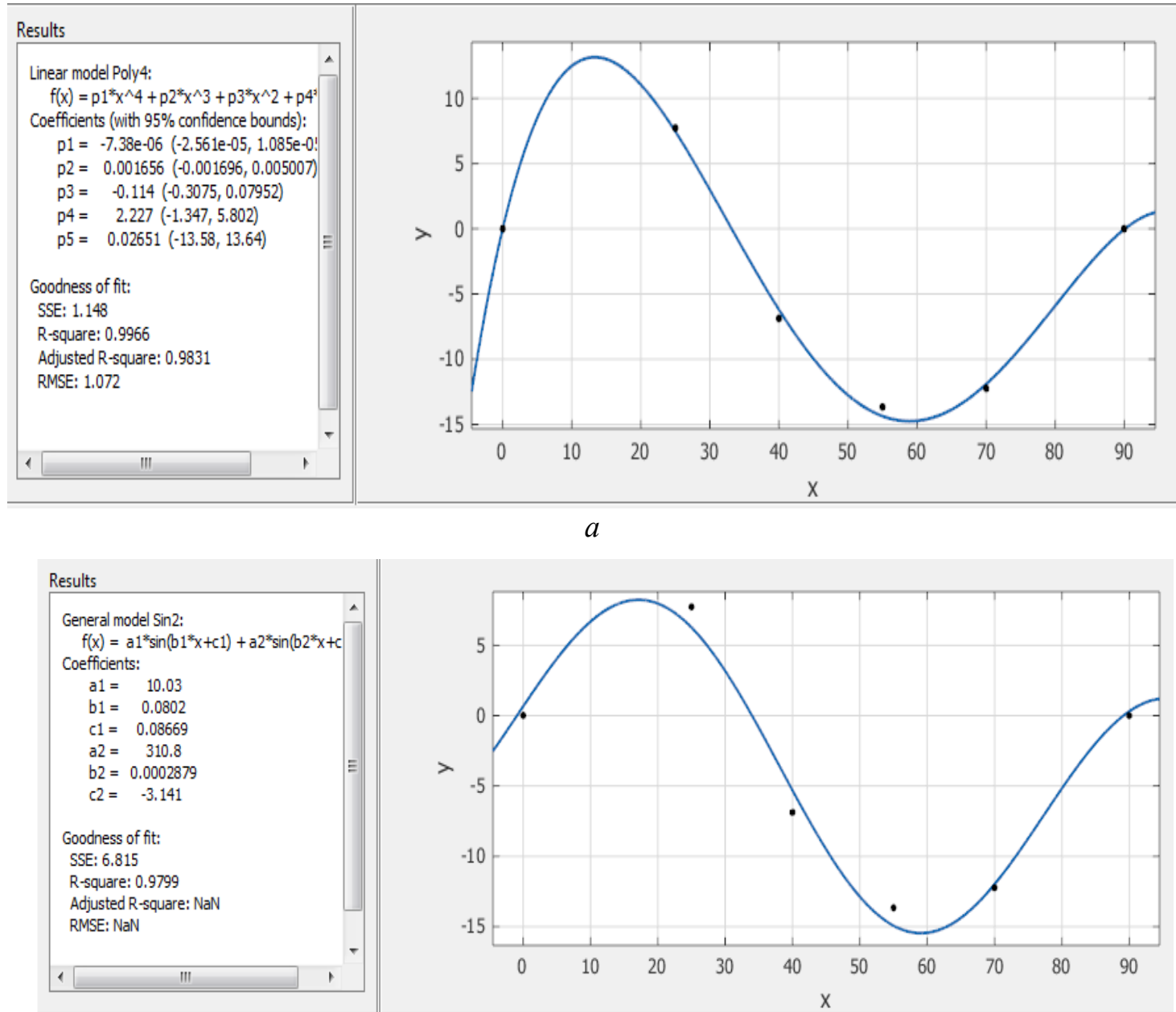

$\sigma$
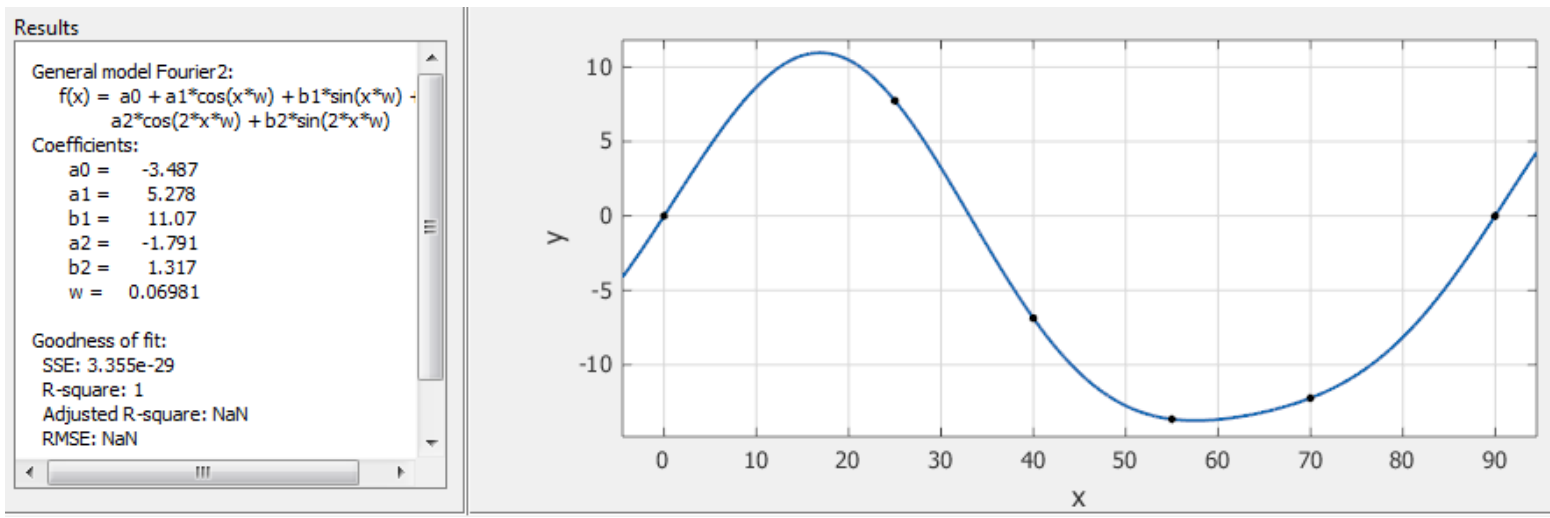

B

Рuc. 4. Апроксимування результуючих характеристик різнорозмірного кульового навантаження млина за першим варіантом різними підходами: $a$ - поліноміальний; $\sigma$ - суми синусів; в - рядом Фур'є 
В процесі апроксимування результуючих характеристик різнорозмірного кульового навантаження млина встановлено, що метод суми синусів дає найгірший результат. Метод Фур'є допускав певні неточності при описанні характеристики відповідно оптимальному складу різнорозмірного кульового навантаження. Поліноміальний підхід забезпечив високу точність апроксимування характеристик за усіма варіантами кульового навантаження. Тому його слід рекомендувати при реалізації даного підходу отримання результуючих характеристик різнорозмірного кульового навантаження млинів. При моделюванні отримані наступні залежності відповідно розглянутим варіантам кульового навантаження млина

$$
\begin{gathered}
f_{1}(x)=-7.38 \cdot 10^{-6} \cdot x^{4}+0.001656 \cdot x^{3}-0.114 \cdot x^{2}+2.227 \cdot x+0.02651, \\
f_{2}(x)=-8.126 \cdot 10^{-6} \cdot x^{4}+0.001856 \cdot x^{3}-0.1278 \cdot x^{2}+2.393 \cdot x+0.01924, \\
f_{B}(x)=7.049 \cdot 10^{-8} \cdot x^{5}-2.274 \cdot 10^{-5} \cdot x^{4}+0.002678 \cdot x^{3}-0.1345 \cdot x^{2}+2.26 \cdot x-6.177 \cdot 10^{-13}, \\
f_{o}(x)=0.0003061 \cdot x^{3}-0.04396 \cdot x^{2}+1.478 \cdot x+0.03706 .
\end{gathered}
$$

Як видно 3 рівнянь (11)-(14), вони відрізняються складністю, що зв'язано з особливостями отриманих результуючих характеристик. Тобто, змінюючи склад кульового навантаження млина, можливо впливати на його результуючі характеристики. Як витікає 3 рівнянь (11)-(14), залежності $f(x)$ будуть тим простіші, чим ближче результуюче різнорозмірне кульове навантаження млина наближається до оптимального.

Критерії оцінювання наближення результуючої характеристики різнорозмірного кульового навантаження до ідеалізованої визначалися в середовищі MathCAD відповідно отриманим в процесі апроксимації математичним залежностям $f(x)$ за усіма варіантами молольного середовища і методами апроксимації. Оцінка критерію оптимальності, наприклад, для першого варіанта кульового навантаження і поліноміального підходу апроксимації приймала наступний вигляд

$$
J_{2}=\int_{0}^{90}\left(-7.38 \cdot 10^{-6} \cdot x^{4}+0.001656 \cdot x^{3}-0.114 \cdot x^{2}+2.227 \cdot x+0.02651\right)^{2} d x .
$$

Результати знаходження значень критеріїв оптимальності зведені в табл. 3.

Таблиця 3. Критерії оцінювання наближення результуючої характеристики різнорозмірного кульового навантаження млина до ідеальної

\begin{tabular}{|c|c|c|}
\hline $\begin{array}{c}\text { Підхід апроксимації ре- } \\
\text { зультуючої характеристи- } \\
\text { ки }\end{array}$ & $\begin{array}{c}\text { Варіант початкового різнорозмір- } \\
\text { ного кульового навантаження }\end{array}$ & $\begin{array}{c}\text { Значення критерію оці- } \\
\text { нювання наближення } \\
\text { характеристик } J_{2}\end{array}$ \\
\hline \multirow{3}{*}{ Поліноміальний } & Перший & 8821,75 \\
\cline { 2 - 3 } & Другий & 15545,26 \\
\cline { 2 - 3 } & Виробничий & 8771,80 \\
\hline \multirow{3}{*}{ Ряд Фур'є } & Оптимальний & 6726,40 \\
\cline { 2 - 3 } & Перший & 8085,19 \\
\cline { 2 - 3 } & Другий & 14766,52 \\
\cline { 2 - 3 } & Виробничий & 8264,38 \\
\hline \multirow{3}{*}{ Сума синусів } & Оптимальний & 6180,52 \\
\cline { 2 - 3 } & Перший & 7199,62 \\
\cline { 2 - 3 } & Другий & 14017,44 \\
\cline { 2 - 3 } & Виробничий & 6482,56 \\
\hline
\end{tabular}

3 даних табл. 3 видно, що значення критеріїв сильно відрізняється як за варіантами різнорозмірного кульового навантаження млина, так і за підходами апроксимування його характеристик. Відповідно першому і другому варіантам кульового навантаження млина значення критерію зменшується в залежності від методу апроксимування — поліноміального, Фур'є, суми си- 
нусів. Така ж залежність спостерігається для виробничого варіанту кульового навантаження, якщо не брати до уваги відсутності значення критерію для суми синусів. Для оптимального значення кульового навантаження млина ці дані змінюються навпаки, що насторожує, оскільки це стосується оптимального кульового навантаження млина. Враховуючи розкриті особливості від підходу апроксимації сумою синусів у даному методі слід відмовитися. 3 даних табл. 3 видно, що підхід апроксимування результуючих характеристик впливає на абсолютне значення критерію. У випадку застосування ряду Фур'є значення критерію занижуються, що може приводити до викривлення результатів. Виходячи зі сказаного, у запропонованому підході отримання результуючих характеристик різнорозмірного кульового навантаження і при визначенні критерію $J_{2}$ необхідно застосувати поліноміальний метод. Він може забезпечує дещо завищені результати самого критерію, але при цьому взаємне розташування результуючої та ідеалізованої характеристик буде оцінюватись більш строго. В результаті моделювання встановлено, що різні варіанти різнорозмірного кульового навантаження мають відмінні значення критерію $J_{2}$. Великий відрив у значеннях $J_{2}$ створюється при дрібному кульовому навантаженні, що логічно можливо пояснити. Найменше значення $J_{2}$ має оптимальний варіант кульового навантаження, що підтверджує правильність даного підходу. 3 одного боку, оптимальне кульове навантаження має характеристику 3 найменшим значенням $J_{2}$, а $з$ іншого боку, воно забезпечує найвищу продуктивність технологічного агрегату як загальну, так і за готовим продуктом. Тому, знаходячи результуючу характеристику з найменшим значенням $J_{2}$, практично будемо гарантувати найвищу продуктивність млина, оскільки оптимальне кульове навантаження перевірялося на практиці. Для нового отриманого результату необхідно лише здійснити експериментальну перевірку отримання найвищої продуктивності кульового млина.

Отже, здійснюючи впливи на різнорозмірне первинне завантаження млина кулями за допомогою відмічених факторів, досягнемо мінімуму оцінки $J_{2}$ і цим самим найкращого складу молольного середовища.

\section{Висновки та перспективи подальших досліджень}

В роботі здійснено моделювання отримання і оцінювання результуючих характеристик крупності різнорозмірного кульового навантаження рудорозмельного млина першої стадії подрібнення. Проаналізовано вплив факторів і розглянуто закономірності спрацювання молольного середовища. Розглянуті характеристики крупності кульового навантаження при однорозмірних кулях та проаналізовано використання суміші різнорозмірного молольного середовища. Розроблено метод побудови результуючої характеристики різнорозмірного кульового навантаження млина. Розроблено критерій оцінювання наближення результуючої характеристики різнорозмірного кульового навантаження до ідеалізованої та доведена можливість його реалізації.

Наукова новизна роботи полягає в тому, що отримав подальший розвиток метод побудови результуючої характеристики крупності різнорозмірного кульового навантаження млина, який, на відміну від відомого, реалізується аналітично, за допомогою персонального комп'ютера, що забезпечує високу точність і продуктивність. Наукова новизна також полягає в тому, що вперше запропоновано критерій оцінювання наближення результуючої характеристики різнорозмірного кульового навантаження млина до ідеалізованої у вигляді квадратичного інтегралу, який повинен мати мінімальне значення і який, на відміну від відомого підходу отримання характеристики відповідно прийнятому кульовому навантаженню 3 наступною виробничою перевіркою досягнутого ефекту, дає відразу результат - оптимальну характеристику і кульове навантаження, який необхідно уточнити на практиці.

Практична значимість роботи полягає в тому, що відразу відкривається перспектива отримання і використання на практиці оптимального кульового навантаження і збільшення продуктивності млинів на $10 \ldots 15 \%$.

Перспективою подальших досліджень $є$ розробка підходів організації практичного використання різнорозмірного кульового навантаження млинів, які забезпечують оптимальне значення продуктивності стосовно каналу молольного середовища. 


\section{Список використаної літератури}

1. Heng W., Minping J. A fuzzy control method for ball mill system based on fill level soft sensor. Proc. Chinese Control and Decision Conference, Guilin, China June 17-19, 2009, pp. 5888-5891.

2. Behera B., Mishra B. K., Murty C. V. R. Experimental analysis of charge dynamics in tumbling mills by vibration signature technique, Miner. Eng., 2007, Vol. 20, pp. 84-91.

3. Huang P., Jia M., Zhong B. Investigation on measuring the fill level of an industrial ball mill based on the vibration characteristics of the mill shell. Miner. Eng., 2009, Vol. 22, pp. 1200-1208.

4. Huang P., Jia M., Zhong B. New method to measure the fill level of the ball mill II —analysis of the vibration signals. Chin. J. Mech. Eng., 2011, Vol. 24, № 4, pp.553-557.

5. Si G., Cao H., Zhang Y., Jia L. Experimental investigation of load behaviour of an industrial scale tumbling mill using noise and vibration signature techniques. Miner. Eng., 2009, Vol. 22, pp. 1289-1298.

6. Pedrayes F., Nornielta J. G., Melero M. G., Menendez-Aguado J. M., del Coz-Diaz J. J. Frequency domain characterization of torque in tumbling ball mills using DEM modeling: Application to filling level monitoring. Powder Technology, 2018, Vol. 323, pp.433-444.

7. George A. Parks. Surface and interfacial free energies of quartz. Journal of Geophysical Research, 1984, Vol. 89, pp. 3997-4008.

8. Баатархуд Ж. Об одном из путей интенсификации процесса измельчения в шаровых мельницах МШЦ $5500 \times 6500$ на комбинате «ЭРДЭНЭТ» / Ж. Баатархуд, Г. Даваацэрэн, Л. Ф. Биленко // Обогащение руд. - 2000. - №3. - С. 3-5.

9. Яценко А. А. О повышении эффективности работы шаровых мельниц на основе использования комбинированной мелющей загрузки / Яценко А. А. // Обогащение руд. - 2011. - №3. - С. 3-5.

10.Хопунов Э. А. Анализ причин низкой эффективности процессов разрушения минерального сырья / Хопунов Э.А. // Современная техника и технология. - 2014. - №10. - С.42-51.

11.Андреев С. Е. Дробление, измельчение и грохочение полезных ископаемых / Андреев С. Е., Перов В. А., Зверевич В. В. - М.: Недра, 1980. - 415 с.

12.Измельчение. Энергетика и технология / [Пивняк Г. Г., Вайсберг Л. А., Кириченко В. И. и др.]. - М. : Изд. дом "Руда и Металлы”, 2007. - 296 с.

13.Мацуй А.М. Моделювання середньозваженої крупності твердого в завантаженні кульового млина рудою і пісками класифікатора./ А.М. Мацуй, В.О. Кондратець // Математичне моделювання. - 2017. - №1 (36). - С. 59-66.

\section{MODELING OF OBTAINING AND EVALUATING THE RESULTING CHARAC- TERISTICS OF A BALL LOAD OF THE ORE GRINDING MILL OF THE FIRST STAGE \\ Matsui A.N., Kondratets V.A.}

\footnotetext{
Abstract

The automatic stabilization of the optimal ball load of the mills in the first stages of ore grinding is currently not carried out, which leads to a significant waste of electricity, balls and lining. Therefore, the solution of part of this problem is quite important.

The aim of the work was to simulate the production and evaluation of the resulting characteristics of different sized ball load of the first stage ore grinding mills.

Solved the problem of analyzing the influence of factors and patterns of wear of balls, modeling the size characteristics with one-dimensional balls, using a mixture of different-sized balls, developing a method for constructing the resulting particle size characteristics of different-sized ball load, developing an evaluation criterion for the approximate and idealized characteristics and the possibility of its implementation.

On the basis of four examples of tasks, a method for constructing a resultant characteristic of the size of a ball of various sizes was developed for the mill and a criterion for estimating the approximation of the resultant characteristic to the idealized one was proposed and the possibility of its realization was proved.
} 
The scientific novelty of the work lies in the fact that the method for constructing the resulting particle size characteristics of a multi-dimensional ball load mill, which is implemented analytically and using a personal computer, has been further developed. The scientific novelty also lies in the fact that for the first time a criterion was proposed for estimating the approximation of the resulting characteristic of a multi-dimensional ball load of the mill to an idealized one. The criterion is a quadratic integral of a polynomial function, which approximates the size characteristic of a multi-dimensional ball loading mill. It should have a minimum value. The method immediately provides for obtaining the best size characteristics and the optimal composition of the ball load.

The practical significance of the work lies in the fact that the prospect of quickly obtaining and using in practice the optimal ball load and increasing the productivity of mills by $10 \ldots 15 \%$ opens up.

The prospect of further research is the development of approaches for the organization of the practical use of a multi-dimensional ball load of mills, which provide the optimal performance value relative to the channel of the grinding medium.

\section{References}

[1] Heng W. and Minping J. "A fuzzy control method for ball mill system based on fill level soft sensor". Proc. Chin. Cont. and Dec. Conf., Guilin, China, pp. 5888-5891, June 2009.

[2] Behera B., Mishra B. K. and Murty C. V. R. "Experimental analysis of charge dynamics in tumbling mills by vibration signature technique", Miner. Eng., vol. 20, pp. 84-91, 2007.

[3] Huang P., Jia M. and Zhong B. "Investigation on measuring the fill level of an industrial ball mill based on the vibration characteristics of the mill shell". Miner. Eng., vol. 22, pp. 1200-1208, 2009.

[4] Huang P., Jia M. and Zhong B. "New method to measure the fill level of the ball mill II —analysis of the vibration signals". Chin. J. Mech. Eng., vol. 24, no. 4, pp.553-557, 2011.

[5] Si G., Cao H., Zhang Y. and Jia L. "Experimental investigation of load behaviour of an industrial scale tumbling mill using noise and vibration signature techniques". Miner. Eng., vol. 22, pp. 1289-1298, 2009.

[6] Pedrayes F., Nornielta J. G., Melero M. G., Menendez-Aguado J. M. and del Coz-Diaz J. J. "Frequency domain characterization of torque in tumbling ball mills using DEM modeling: Application to filling level monitoring". Powd. Techn., vol. 323, pp. 433-444, 2018.

[7] George A. Parks "Surface and interfacial free energies of quartz". Jour. of Geoph. Res., vol. 89, pp. 3997-4008, 1984.

[8] Baatarkhud Zh., Davaatseren G., Bilenko L. F. Ob odnom iz putei intensifikatsii protsessa izmel'cheniya v sharovykh mel'nitsakh MShTs 5500kh6500 na kombinate «ERDENET» [On one of the ways to intensify the grinding process in ball mills MShTs 5500x6500 at the "ERDENET" plant]. Obogashchenie rud, 2000. no.3, pp. 3-5. (in Russian).

[9] Yatsenko A. A. O povyshenii effektivnosti raboty sharovykh mel'nits na osnove ispol'zovaniya kombinirovannoi melyushchei zagruzki [On improving the efficiency of ball mills through the use of a combined grinding load]. Obogashchenie rud, 2011. no.3, pp. 3-5. (in Russian).

[10]Khopunov E. A. Analiz prichin nizkoi effektivnosti protsessov razrusheniya mineral'nogo syr'ya [Analysis of the reasons for the low efficiency of processes of destruction of mineral raw materials]. Sovremennaya tekhnika i tekhnologiya, 2014. no.10, pp. 42-51. (in Russian).

[11] Andreev S. E., Perov V. A., Zverevich V. V. Droblenie, izmel'chenie i grokhochenie poleznykh iskopaemykh [Crushing, grinding and screening of minerals]. Moscow, 1980. 415 p. (in Russian).

[12]Pivnjak G. G., Vajsberg L. A., Kirichenko V. I., Pilov P. I., Kirichenko V. V. Izmel'chenie. Jenergetika i tehnologija [Grinding. Energy and technology]. Moscow, 2007. 296 p. (in Russian).

[13]Macuj A. M., Kondratec' V. O. Modeljuvannja seredn'ozvazhenoi' krupnosti tverdogo v zavantazhenni kul'ovogo mlyna rudoju i piskamy klasyfikatora [Modeling the weighted average grain size in the ball mill loading with ore and sand classifier]. Matematychne modeljuvannja, 2017. no1 (36), pp. 59-66. (in Ukrainian). 